\title{
Classification and resolution procedure for disputes in public construction projects
}

Mahmut Sarı (Main Author)

Ahi Evran University, Vocational School of Technical Sciences, Kırşehir

40200 (Turkey)

mahmutsari@ahievran.edu.tr

https://orcid.org/0000-0002-9298-5518

Baris Sayin (Corresponding Author)

Istanbul University-Cerrahpasa, Department of Civil Engineering, Istanbul

34320 (Turkey)

barsayin@iuc.edu.tr

https://orcid.org/0000-0002-2437-1709

\section{Cemil Akcay}

Istanbul University, Department of Architecture, Istanbul

34116 (Turkey)

cakcay@istanbul.edu.tr

https://orcid.org/0000-0002-8216-8688

Manuscript Code: 15464

Date of Acceptance/Reception: 08.08.2021/18.06.2020

DOI: 10.7764/RDLC.20.2.259

\begin{abstract}
Construction sector, which is associated with approximately two hundred sub-sectors in terms of employment area, plays the role of locomotive sector in economic development of countries. This feature of the sector affects economy directly and indirectly. Despite this positive contribution of the sector, disputes are inevitable between parties -administration and contractor- in a bid, contract and implementation processes, which are parameters of the construction process. Formal judicial process applied for the purpose of resolving disputes encountered in construction projects that the public assumes the role of employer, takes a long time. Therefore, while contractor is exposed to financial losses, administration cannot conclude public investment. In the study; disputes in public construction projects are classified, and proposals preventing disputes are presented. In this scope, firstly, 174 of 10591 disputes submitted to Court of Cassation, and 84 of 102 disputes submitted to Directorate of High Technics Board are selected regarding public construction projects. In the second stage, parameters causing disputes are classified under six main items. Thirdly, reasons of the disputes for each classification are detailed, and then proposals are presented for prevention of the disputes based on FIDIC (International Federation of Consulting Engineers) contract forms. Finally, a resolution procedure is developed for the processes including bid, contract and implementation phases based on FIDIC. By the presented proposals for GCCW (General conditions of construction works) official resolution paths can be reduced to a minimum, and the processes result positively for administration and contractors. It is concluded that the developed procedure is suitable as a practical tool for resolution process of the disputes in the public construction projects.
\end{abstract}

Keywords: construction sector, public investment projects, dispute classification, dispute resolution, FIDIC red book.

Construction industry, which has a $15 \%$ share in international economy, directly impresses development and acceleration of a country's economy (INTES, 2018; KPMG, 2018). In parallel, share of construction sector in economy of countries is increasing at the present time. Considering shares of public and private sectors in this development, the fact that public construction projects play a key role in development policies increases importance of these projects. Main purpose of public construction projects is to provide goods, works and services for benefit of society. Compared to purchasing goods and services, construction works are projects that influence welfare and comfort level of society. Public construction projects include many construction works such as building, highway, railway, highway, airport, dock, port, shipyard, bridge, tunnel, metro, viaduct, sports facility, infrastructure, pipe transmission line, communication and energy transmission line, dam, power plant, refinery plant, irrigation plant, land reclamation, flood protection and pickling etc. In addition, installation, manufacturing, export, transportation, completion, repair, restoration, landscaping, drilling, demolition, strengthening and assembly works are also evaluated within the scope of public construction works. While only parties are affected by the benefits and harm that occur during implementation of construction projects between real persons, the society is affected by the benefit and loss in the construction works where one of parties is public. For this reason, it is necessary to avoid waste of resources and approaches that cause public loss during implementation of public construction projects (Aydemir, 2016; PMI, 2013). Public benefit is provided if public construction projects are carried out in accordance with the planned cost, duration and quality criteria. 
Moreover, public resources are not wasted and investments can be carried out as planned. However, there may be disputes between parties at any stage of public construction projects. Afterwards, planned process is delayed if dispute cannot be resolved correctly and urgently. In this case, i. realization of investment is interrupted, ii. total cost, duration and quality vary, and iii. parties are exposed to pecuniary loss. Again, if a dispute is not evaluated by judicial authorities in accordance with technical criteria, parties are adversely affected. In project management, dispute is inevitable and the most common types of disputes are; i. manpower resources, ii. equipment and facilities, iii. capital expenditures, iv. costs, v. technical opinions and barters, vi. priorities, vii. administrative procedures, viii. planning, ix. responsibilities, and x. personality disputes (Kerzner, 2009; Zikman, 1992).

Disputes encountered in public construction projects as well as in the construction sector occur during the contract phase and implementation phase of the contract. In this respect, the reasons for dispute in the construction works are listed as; i. failure to do a work in accordance with the contract and its annexes and at the specified time, ii. failure to take occupational health and safety measures, iii. work that is not at the desired level in terms of cost, duration and quality, iv. inspection process of applications, and v. temporary and final admission (FIDIC, 2015). Studies are carried out in the literature regarding disputes in the construction industry. In a study, in addition to applications of the Public Procurement Law no. 2886 in construction sector, articles that are mostly referenced for resolution of dispute are examined in General Conditions of Public Works. Afterwards, judicial decisions regarding these disputes are examined, and resolution proposals are offered based on dispute reasons (Bilaloğlu, 1995). In another study, proposals for content of contract that prevented disputes as well as points that should be considered to reduce contract-induced disputes are specified (Uyanık, 2004). Turkey and in world by selecting arbitration path dispute's resolution has also been studied in the literature (Bozkurt, 2002). Based on the legal dimension of a concept of contract, causes and solutions of disputes in construction industry is examined in specific cases in Court of Cassation (Eken, 2005). In a study carried out by Apanoglu (2007), disputes -duration of construction and fault / care debts of contractor- are examined, which has the highest rate in disputes handled in judiciary. In this scope, necessary steps are specified to prevent disputes. Koldaş (2008) investigated standard contracts and resolution process of a dispute as well as FIDIC's scope. Mersinkaya (2010) examined the concepts of dispute and disputes that may be exposed in construction contracts. Thus, it is revealed that definition and effects of concepts in construction sector. In another study, the solution of the disputes which are encountered in the stage of implementation of the contract in public construction projects investigated by calculating the defect rates of parties -employer and contractor- via the fuzzy logic model (Öz, 2012). In a research carried out by Çakmak, pre-contract and implementation stages of public construction projects are examined and compared with international standard contracts (Çakmak, 2014). By this comparison, it is presented that contract model and suggestions for the resolution of disputes. Genç (2014) has examined the disputes in turnkey project -lump sum pricecontracts in public projects and presented proposals for choice of arbitration path in resolution of disputes. In a study performed by Erel, Public Procurement Legislation and FIDIC Red Book are compared (Ereli, 2014). Based on the data obtained in this comparison, resolutions are proposed for the improvement of legislation. In an another study, causes and rates of disputes in construction-related law-suit are determined. In addition, quality and competence levels of all stakeholders -judge, administration, contractor- in the law-suit process are examined (Çevikbaş, 2018). Examining the causes of disputes in the contract and implementation stages for construction projects, it is seen that dispute is inevitable (Langford, Kennedy \& Sommerville, 1992). As a similar approach, it is emphasized that the dispute is a construction-specific situation and that there are ninety-four different forms of standard contract in the industrial sector of England as a result of this inevitability (Hellard, 1992). Another study states that problems and disputes in construction industry are the result of misunderstanding. In addition, it is stated that it is the result of a lack of training process for professionals in the construction industry, causing disputes (Hankock, 1992). In another view, the disputes in the construction sector are sector-specific, and it is stated that reason for this is the way the industry works (Smith, 1992). In a study examining disputes involving contractor deficiencies or alleged deficiencies, disputes contractor/subcontractor-induced deficiencies are determined to be $15 \%$ of all disputes (Watts \& Scrivener, 1992). Chan and Kumaraswamy stated that delays are generally caused by administration-induced changes, unforeseen field conditions, poor management in the field and slow decision-making (Chan \& Kumaraswamy, 1997).

Although there are studies in the literature regarding the disputes occurring in public investment projects in construction sector, studies for results of any disruption, delay or failure to construct a desired quality in public investments have not been sufficiently examined. In the study carried out by considering this deficiency; firstly, the causes of disputes in public construction projects are analyzed, and then resolution proposals are given to prevent parties identified as administration and contractor from falling into dispute over similar issues. Within the scope of the study; i. causes of disputes occurring in public construction projects are classified based on the decisions of Court of Cassation and Directorate of High Technics Board, ii. for disputes encountered in construction projects, resolution procedure is developed based on FIDIC (2017), which presents international standard contracts, and resolution procedure is given for deficiencies and inconveniences in construction stage. 
Disputes in public construction projects are resolved using three approaches, namely; official resolution, standard contracts and alternative dispute resolution (Figure 1). This study focused on formal solutions and standard contracts. In this section, the solution process of these two approaches is explained.

Figure 1. Resolution paths to public construction disputes in Turkey. (Self-Elaboration).

\section{Official resolution paths}

The first step to resolve disputes that occur during implementation of public construction projects is to reach a new agreement by parties for resolution of dispute. In this respect, issues that cause parties to have different views should be discussed and it is in favor of parties to reach a new agreement without misunderstanding (Çakmak, 2014). Disputes can be resolved through arbitration provided that it is within the scope of contract. In addition, some disputes can be resolved using conciliation approach. For example, cases that there are claims about not paying price of goods or services or dissatisfaction with service provided are a suitable approach for solution using conciliation approach. By contrast with, resolution using conciliation is not possible if parties disagree on the articles of a contract or when parties do not compromise (Goodman, 2017). If parties cannot agree on dispute, and object to solution through arbitration or conciliation approach is not suitable, authority to be applied is an official judgment. Official solutions have long, costly and mandatory actions. The fact that the result obtained at the end of process is binding and strict is one of distinguishing features of this solution path. Within the scope of all this information, two resolution paths, namely official judgment and arbitration, are chosen to resolve disputes that occur during implementation of public construction projects.

In addition to the aforementioned resolution paths, Public Procurement Authority and High Technics Board (HTB) play a key role in the resolution of complaints, and disputes that occur during implementation of the contract, respectively (HTB, 2015). HTB has duties such as making binding and non-binding decisions for the resolution of construction contract-induced disputes upon request of administrations as well as preparing and publishing standard contracts, unit prices and specifications. Appeals are submitted to HTB for the purpose of requesting opinions and decisions in resolving disputes during implementation phase of public construction projects. Although the applications made by employer/administration are evaluated, the applications of contractor are not evaluated. Nevertheless, there is a condition that the dispute minutes must be prepared together by parties in order for the application regarding the unit price dispute to be evaluated by the Board. Also, it is not considered applications which is defined out of assigned position of HTB or issues in the judicial process. HTB's decisions regarding new unit price-induced dispute are final and binding on parties. After all, judicial remedy is available in the decisions. Opinions and decisions given by HTB are taken 
into consideration by administrative and judicial authorities in practice. There are also provisions to get the opinion of the board about the disputes that occur in public construction projects based on FIDIC standard contract form (Kerzner, 2009).

\section{Jurisdiction path}

There may be situations that judgment is preferred instead of arbitration for resolution of disputes in implementation process of construction projects: i. hope for strictly and quickly resolution of dispute, ii. laws and regulations-induced legal dispute, iii. confusion during the arbitration process depending number of parties, and iv. positive opinion about dispute's resolution for one of parties (Eken, 2005; Murdoch \& Hughes, 1992). In public construction projects, while administrative courts are responsible for resolution of disputes in process until signing of contract, judicial courts are in charge with resolution of disputes during implementation of projects. In appeal process in administrative jurisdiction, first instance administrative courts, second instance administrative courts (Regional Administrative Courts) and ultimately Council of State are authorized. In addition to this, appeal process in judicial justice, first instance court for administrative jurisdiction (civil- and criminal-courts), second instance court courts (regional courts of justice) and ultimately Court of Cassation are authorized. Judicial courts are competent institution for disputes during implementation phase of public construction projects.

\section{Arbitration path}

Arbitration is a process in which the competent unit is judged in place of official jurisdictions to resolve of the dispute between parties (Koral, 1947; Balcı, 1999; Fenn \& Gameson, 1992). In another definition, arbitration is a legal institution that allows it to be resolved by persons without official status. As such, arbitration is a system that an authorized person selected by individuals to resolve of disputes between parties (Garsonnet, 1912). The process of the formation and spread of the arbitration mechanism has accelerated due to the development and globalization of international trade. With the removal of barriers to trade and the impact of globalization, countries have been included in international agreements related to arbitration and updated their national laws (Uyanık, 2004). The process is carried out by neutral arbitrator or arbitral tribunal as a result of all specified legal processes. This process is a formal method that complies with the arbitration rules in Civil Procedure Law and allows for a binding decision in accordance with international conventions. Depending on whether the dispute includes a foreign factor or not, law that is used in the arbitration and solution varies. If parties are citizens of Turkey and dispute process is being carried out in the country, it is based on The Civil Procedure Law in dispute. However, if the disputes are of foreign origin, International Arbitration Law, International Private Law and Procedural Law Act are based. Arbitration agreement may be related to the content of contract or to resolve all or some disputes. Arbitration Center Istanbul, Turkey Bar Association Arbitration Center, Istanbul Chamber of Commerce Arbitration and Mediation Center are important arbitration centers in Turkey. Again, there is an International Arbitration Center at the international level (ICC, 2012; ISTAC, 2017; ISTAC, 2018; ITOTAM, 2017; TBA, 2002).

\section{Resolution paths according to standard contracts}

Total project cost undertaken by Turkish construction companies operating abroad since 1972 has reached 381.1 billion USD (OCTC, 2019; TMB, 2019). Companies undertaking international construction projects frequently encounter FIDIC and FIDIC-based contracts in various countries (FIDIC, 2019a; FIDIC, 2019b). World Bank and many credit institutions require the use of FIDIC standard contracts in construction projects for which they provide financial support. The use of FIDIC standard contract forms in $30 \%$ of international construction projects shows the acceptability and prevalence of this standard. According to the International Chamber of Commerce (ICC) data, approximately $21 \%$ of appeals arbitration are related to contracts prepared according to FIDIC standard forms (Bilaloğlu, 1995). Administrations have authority to use FIDIC contracts based on the third article of the Public Procurement Law. FIDIC rules are based on foreign-induced loans financed public works project in Turkey. As an example of projects can be given as; i. Marmaray project, ii. Earthquake dwellings in Kocaeli and Erzincan, iii. Light rail projects in cities of Adana, Bursa, Kayseri and Samsun, iv. Baku-Tbilisi-Ceyhan oil pipeline project, and v. A part of the Istanbul-Ankara motorway (Aydın, 2010).

\section{International Federation of Consulting Engineers (FIDIC)}

FIDIC is the international representative of national consulting engineers associations, representing 40,000 companies in more than a hundred countries worldwide, with more than a million experts. Established in Lausanne, Switzerland in 1913, FIDIC prepares and publishes international pre-qualification forms and standard contract forms for customers, consultants, sub-consultants, joint ventures and representatives. ICE (British Chamber of Civil Engineers), which accepted the construction projects to be subject to the standard contract in 1945 and carried out the first work, 
constitutes the founding philosophy of the federation. FIDIC forms, the first of which was published in 1957, were updated in 1969, 1977, 1987, 1999 and finally in 2017, respectively. Various books related contract conditions are prepared by FIDIC in terms of design, project and responsibility. Among these, the most common ones in practice are listed as; i. Red book (building and engineering contracts planned and designed by administration), ii. Yellow book (construction contracts planned and designed by contractor), iii. Silver book (turnkey project contracts that contractor has undertaken all the works), iv. Green book (recurring project contracts that are expected to be completed in less than half a million dollars and / or less than six months), v. Orange book (contract sample and specification for designbuild / Turnkey works where design is made by contractor), vi. White book (employer / consultant engineer standard service contracts), vii. Golden book (contracts for design-build-operate projects), and viii. Blue-Green book (contract terms for dredging and filling works) (KiK, 2017).

FIDIC Red Book, based on this study, has been widely used for twenty years. In projects that a design provided by administration, extensive updates are presented in 2017 version in terms of balancing the risk distribution between the employer and contractor, expanding the engineer's authorities, and eliminating the uncertainties about work duration. The flow diagram for evaluation process of requests submitted to FIDIC is given in Figure 2. In the process, the decision of FIDIC delegation must be informed as reasoned within 84 days after the request is received. The delegation's decision is binding for both parties. If either party is not satisfied with decision of the delegation, one of parties may issue notice of dissatisfaction (NOD) to the other party within 28 days of the decision. However, if the delegation does not disclose its decision within 84 days, one of parties may issue a NOD to the other party within 28 days from the time of the deadline. If there is no the notice given by either party within 28 days of the decision, the decision is final and binding. If there is the notice against the delegation decision of any party, the way of negotiation should be chosen before applying for a resolution via arbitration. In this process, negotiation is managed by the delegation. If parties have not applied for the negotiation process, the arbitration procedure will be opened 28 days after NOD. At the end of all the processes, no provided that resolution has been reached by delegation decision or negotiation, arbitration is applied for the resolution of the dispute (Öz, 2012).

Figure 2. Resolution procedure of dispute according to FIDIC Red Book Second Edition 2017 (in Figure: DAAB- Dispute Avoidance/Adjudication Board) (FIDIC 2017)

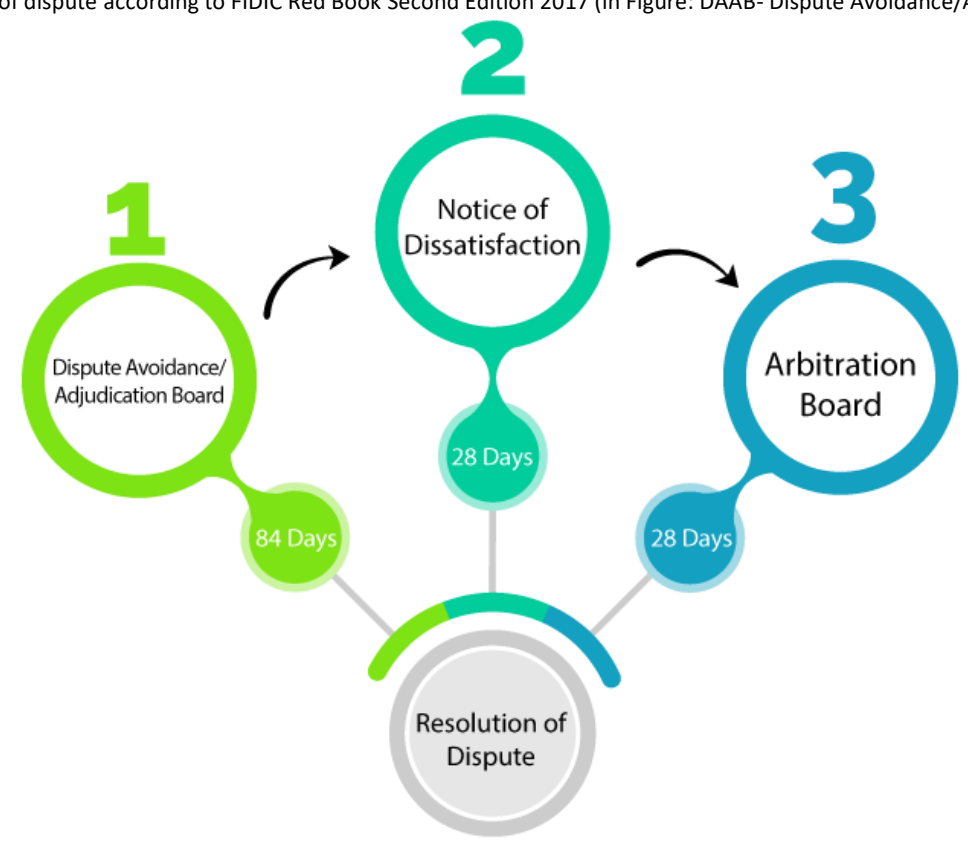

\section{General conditions of construction works (GCCW)}

GCCW includes general principles and contract terms that are taken as basis during implementation phase of public construction projects. Aim of this specification is to determine the general principles of construction works under Public Procurement Contracts Law. The scope of the specification is construction works of all administrations based on Public Procurement Authority and Public Procurement Contracts Law. The mentioned specification consists of provisions that include the responsibilities, authorities, supervision of works, delivery processes, execution processes, admission procedures and general legal and administrative conditions in contract during implementation of public construction projects. Disputes between contractor and building inspection officer regarding final calculations or execution of work during implementation of public construction projects are based on process specified in conditions (Figure 3). 


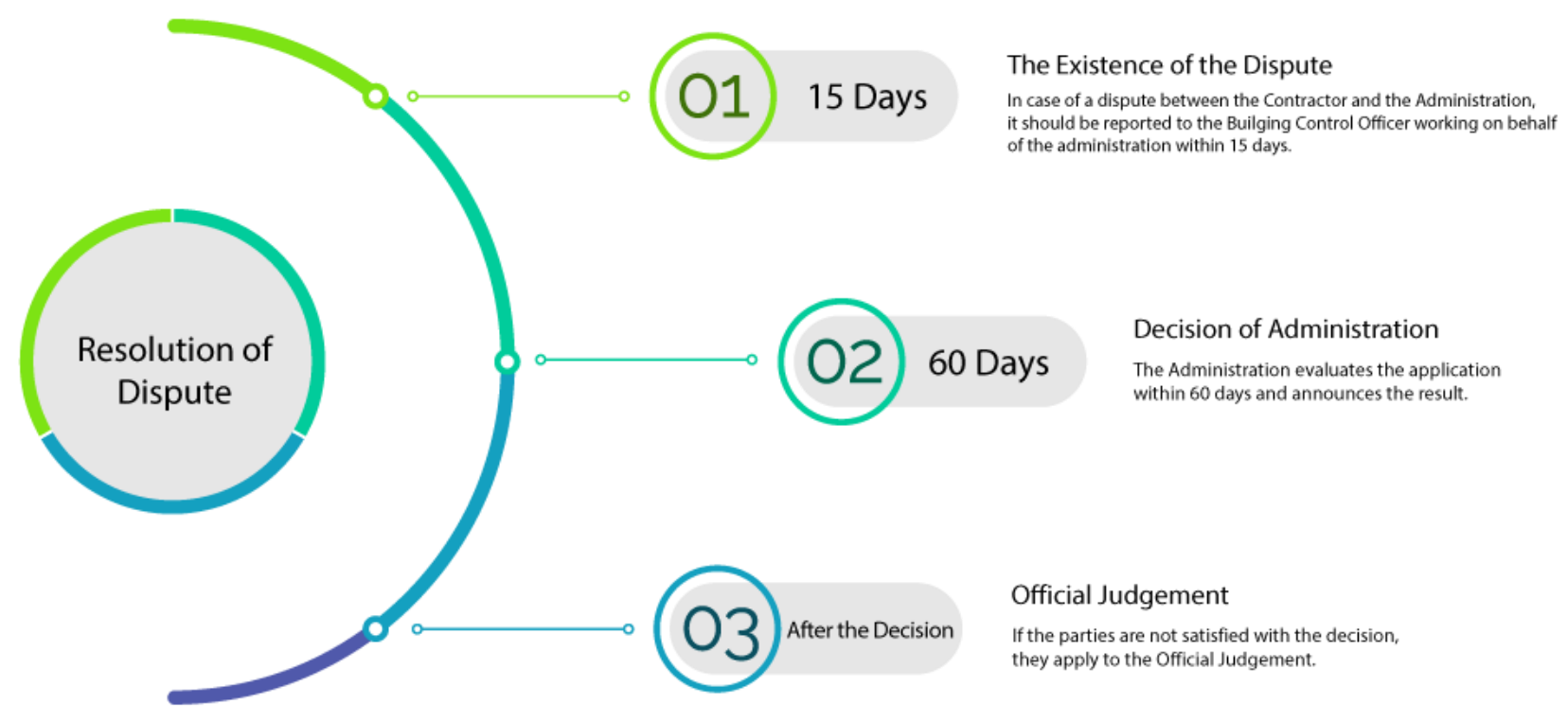

Results and discussion

Court of Cassation is the ultimate resolution authority in official judgment of disputes that occurred during implementation phase of public construction projects. The Court decisions regarding disputes that occurred in public construction projects between 2015 and 2018, are examined in this study, since the Court have authority to supervise the decisions of first instance courts and took decisions that bind all the judicial authorities. In reaching the case documents submitted to the Court, it is used that the archive of the institution and comprehensive legal databases as well as the publications of lawyers specialized in their fields. The purview of Law Department no.15 of Court of Cassation covers disputes arising in public construction projects. In the period between 2015 and 2018, 10591 decisions are decided in this court. By analyzing the decision cases, 174 decisions were determined that the public is an employer one of the parties- and the reason for the dispute is understandable. The decisions are sorted based on; i. merits no, ii. decision no, iii. decision date, iv. contract type, v. reasons for the dispute, vi. results of the dispute, vii. law, specification and regulation articles regarding the dispute, viii. winning party information, ix. judgment type, and $\mathrm{x}$. justified decision features. In decisions, articles of law are determined, which are taken as reference of reasons and resolution offers for the disputes in public construction projects. The laws containing the articles are determined as Public Procurement Authority, Public Procurement Contracts Law, Legal Procedures Law, Turkish Code of Obligations, Code of Obligations, GCCW, Fees Act and Abolished Foundations Code. The reason for the dispute is determined on the basis of these articles, and a solution proposal is presented.

In public construction projects, administration may request decisions and opinions from HTB of Ministry of Environment and Urbanization before carrying out administrative action regarding the dispute. It is examined that 102 consultancy comments and decisions of HTB that are not legally binding on the disputes that occurred in public construction projects performed between 2005 and 2015. As a result of this review, 84 comment and decisions, whose reasons for dispute are understandable in implementation phase of public construction projects, are identified and evaluated within the scope of the study. Disputes are classified by reviewing decisions of Court of Cassation and HTB, and proposals are presented for the resolution of the disputes. Then, the reasons for the dispute are classified as six main items. Distribution of causes of dispute is shown in Figure 4. According to decisions of Court of Cassation and HTB, the most reason for disputes between parties is about increase or decrease in work (Table 1). The correctness of the classification for disputes is confirmed by determining the articles of law based on the causes of the dispute (Table 2). 
Figure 4. The distribution of dispute reasons according to decisions of (a) Court of Cassation, (b) HTB. (Self-Elaboration).
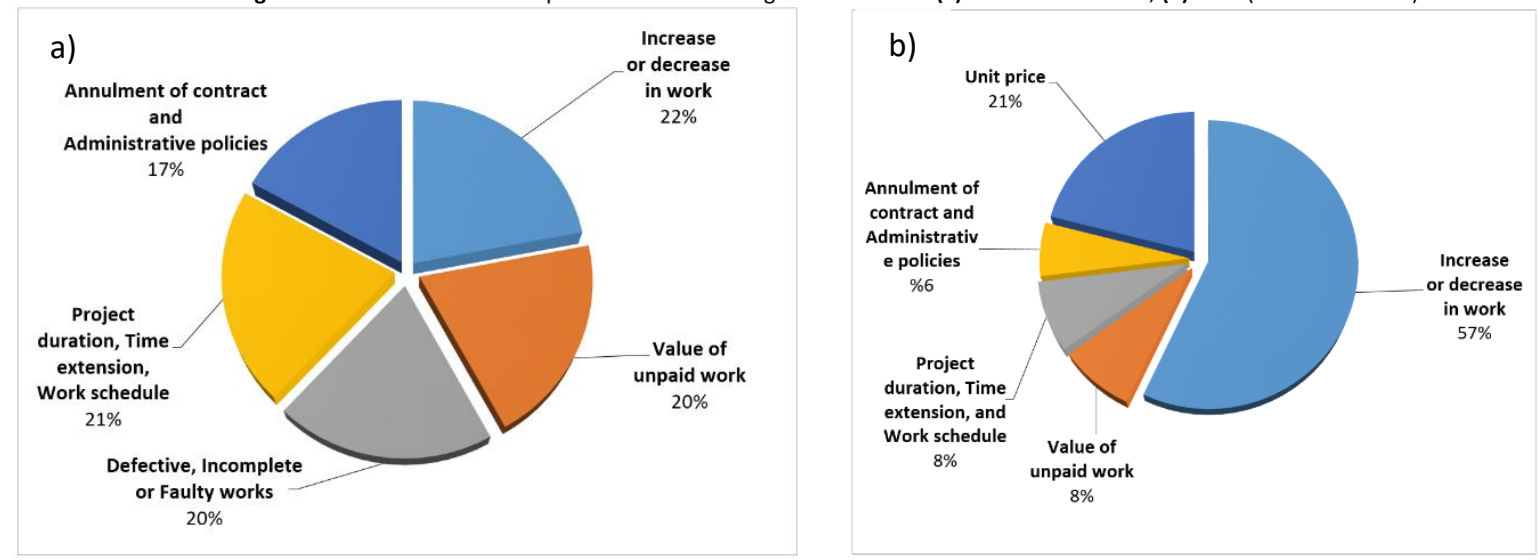

\begin{tabular}{|c|c|c|c|c|c|}
\hline \multirow{2}{*}{ ID } & \multirow{2}{*}{ Dispute classification } & \multicolumn{2}{|c|}{ Court of Cassation } & \multicolumn{2}{|c|}{ HTB } \\
\hline & & Count & $(\%)$ & Count & (\%) \\
\hline$A$ & Increase or decrease in work & 38 & 22 & 48 & 57 \\
\hline$B$ & Value of unpaid work & 35 & 20 & 7 & 8 \\
\hline C & Defective, incomplete or faulty in work & 35 & 20 & - & - \\
\hline$D$ & Project duration, time extention, work schedule & 37 & 21 & 7 & 8 \\
\hline$E$ & Contract's annulment and administrative policies & 29 & 17 & 5 & 6 \\
\hline \multirow[t]{2}{*}{$F$} & Unit price & - & - & 17 & 21 \\
\hline & Total & 174 & $100 \%$ & 84 & $100 \%$ \\
\hline
\end{tabular}

\begin{tabular}{lccccc}
\multicolumn{5}{c}{ Table 2. Laws based on dispute classes and the corresponding article number in the law. (Self-Elaboration). } \\
\cline { 2 - 6 } Law & A & B & C & D & E \\
\hline Turkish Code of Obligations & 5 & 5 & 7 & 5 & 4 \\
The Civil Procedure Law & 12 & 8 & 10 & 12 & 9 \\
Code of Obligations & 6 & 8 & 13 & 6 & 7 \\
GCCW & 5 & 3 & 2 & 5 & 3 \\
Public Procurement Law & - & - & - & - & - \\
Fees Act & 1 & 1 & - & 1 & 2 \\
Abolished Foundations Code & 2 & - & 4 & 2 & 3 \\
\hline
\end{tabular}

\section{Increase or decrease in work-induced dispute}

Depending on unforeseen situations during implementation of the contract, an increase or decrease in the planned amount of work can occur. Administration has the authority to make the necessary changes in cases where it is not possible to complete the work with the existing projects under the contract. Depending on these changes, there is a required additional costs and duration due to the increase of work that contractor has to complete. The decrease in work is added to agenda in case of the possibility of finishing project with less than $80 \%$ of the contract value. There may be a dispute between parties in terms of increase and decrease in work in the processes. In this case, public service is interrupted due to prolonged process, and parties are exposed to pecuniary loss and intangible damages. This dispute class in Court of Cassation is covered as; i. work increase based on contract, ii. work increase based on contracting out, and iii. request for surplus charges based on enactment of Council of Ministers. Similarly, the class in HTB is grouped as; i. work increase based on contract, ii. work increase based on contracting out, and iii. request for surplus charges (Figure 5). Distribution of winning party based on decisions of Court of Cassation and HTB is given in Figure 6. Almost all of the decisions (97\%) of local court regarding this dispute are reversed by Court of Cassation. 
Figure 5. Increase or decrease-induced dispute distribution according to decisions of (a) Court of Cassation, (b) HTB. (Self-Ealboration)

(a) Increase work based on contract $\% 16$ tract
Request for surplus charges based on nactment of cour $5 \%$

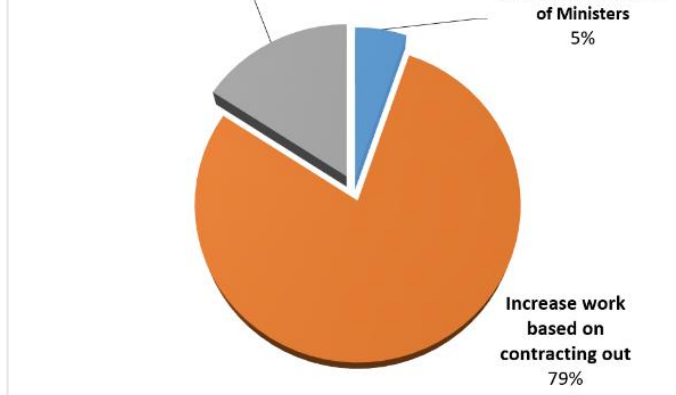

(b)

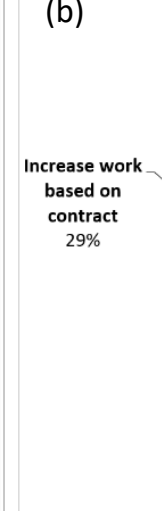

Figure 6. Results of winning party in increase or decrease-induced dispute. (Self-Elaboration).

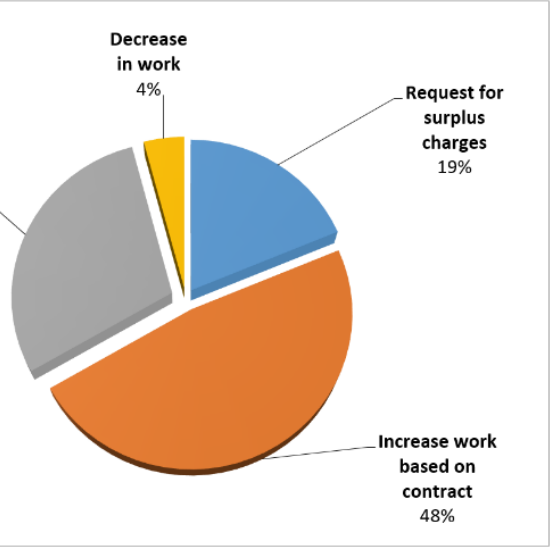

(1) Court of Cassation $\mathrm{NHTB}$

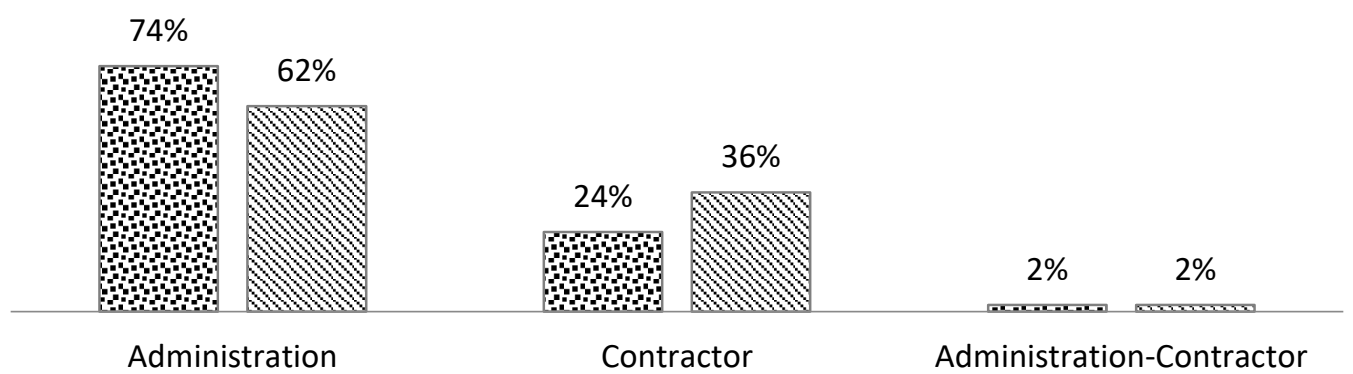

Cases that cause increase or decrease-induced disputes, its preventive measures are given in six items based on 38 and 48 decisions in Court of Cassation and HTB, respectively.

- Project and details are inadequate and incompatible due to insufficient preparation duration of construction projects. Depending on this reason, there is a need for work increase in- or out of-contract during application phase of projects. In order to avoid this need, arrangements should be made to ensure that project preparation duration is extended sufficiently, provided that it does not disrupt bid processes. In addition to this, project reviews are required. It should be ensured that administrative staff to conduct the reviews have sufficient knowledge and experience, and trainings should be provided for their professional development.

- A contractor cannot trust the objective of administration, which is a party to contract in determining amount and price of work increase, as it is decision maker in resolution of the dispute. Dispute developed between parties is transferred to official judiciary because contractor has no right to apply to HTB delegation and there is no alternative solution. In official judicial process, expert commissions, assigned by local courts determining amount and value of work increase including -in- or out of-contract, make mistakes due to incomplete reviews. Technical, financial and administrative supervision of public construction projects are carried out by supervisor, chief and engineer. The fact that staff appointed as building inspectors are administrative staff causes suspicion at the point of objectivity. As a result of this reason, it is clear that the supervisor cannot perform duty of the engineer defined in FIDIC. The fact that the building supervisor works on behalf of administration and respects the public interest in all processes of project causes formation and development of the dispute. In addition to the technical and financial obligations on behalf of administration, the duties and authorities of the engineer defined in FIDIC in resolution of disputes between parties do not coincide with that of building inspector defined in GCCW. Changes to GCCW must be made to ensure negotiation. An objective engineer authorized resolving mediation and dispute must be identified in GCCW, as in FIDIC Red Book. The decision made by the engineer is not binding for parties. However, an objective decision can be taken in a short compared to the long and costly process in the official judiciary. If parties are not satisfied with the decision of the engineer, Dispute Avoidance/Adjudication Board (DAAB) consisting of three people are formed before the official judgment process. It is suggested that the board be defined in GCCW as it has a positive contribution in terms of duration and cost in the process.

- In public construction projects included in GCCW, increase in work is done in cases that it is impossible for out of contracted project. In this scope, increase value in work, up to $10 \%$ for turnkey lump sum and up to $20 \%$ for unit price method contracts, are paid based on unit price in the contract. The upper limit set in GCCW is insufficient for some projects and in search of different resolutions in case of an increase in work above the 
limits. In this case, contractor stops the work or administration can annulment of contract. There is no upper limit for the work increase price in FIDIC standard contracts compared to the upper limits set in GCCW for value of increase in work. The increase in the amount of work in FIDIC is determined based on the budget allocated by administration depending on the contract. In this respect, GCCW should be revised in order to determine project increase value according to characteristics of public construction projects.

- It is a condition that contractor can perform the work in accordance with the technical specifications and projects are complete and compatible. The absence in project of work items in the technical specifications, which is the annex of the contract, causes a problem in implementation process. Thus, the difference of opinion on whether the production completed is evaluated as an increase in business leads to dispute. For this reason, contractor must examine the technical specifications and project, which are annexes of the contract, and check their compatibility by comparing them during the bidding phase. Thus, disputes can be prevented by forwarding to administration possible incompatibilities identified. To this end, contractor staff should have the experience and knowledge to absorb the contract and its annexes at the bid stage. Moreover, implementation guides should be included in GCCW, similar to implementation guidelines of FIDIC standard contracts.

- The requests that contractor which is deserved regarding the dispute should be prevented. To this end, administration should make arrangements to have project managers with sufficient technical and legal knowledge and experience working in contractor firm.

- Examining the decisions of Court of Cassation and HTB on the increase and decrease in work-induced disputes, it is understood that a resolution can be reached in a shorter duration and less cost by choosing a negotiation method compared to the official judgment path. In order to ensure negotiation, first, arrangements must be made in GCCW to meet the demands of parties such as duration extension, reasonable profit, meeting the expenses. The current law and GCCW include biased provisions that prioritize public interest. Similar to FIDIC Red Book, the requests of parties, the application process, and decretive about the demand must be defined in detail.

\section{Value of unpaid work-induced disputes}

It causes dispute between parties due to the circumstance that the fee deserved by contractor is not paid for various reasons or for no reason. The dispute of unpaid work-induced dispute constitutes $20 \%$ and $8 \%$ of the dispute determined based on Court of Cassation- and HTB-decisions, respectively. The dispute class in Court of Cassation-decisions occurs under the titles as; i. value of unpaid work, ii. late payment of work value, and iii. objection to be commenced execution proceeding for value of unpaid work. Similarly, this dispute in line with HTB decisions is categorized as; i. value of unpaid work, and ii. interruption in work value (Figure 7). The results of the Court- and HTB-decisions for the winning parties are presented in Figure 8 . While the Court reversed $94 \%$ of the decisions of local court regarding the dispute class, it approved remedially $6 \%$ of them.

Figure 7. Distribution for unpaid work value-induced disputes according to decisions of (a) Court of Cassation, (b) HTB. (Self-Elaboration).

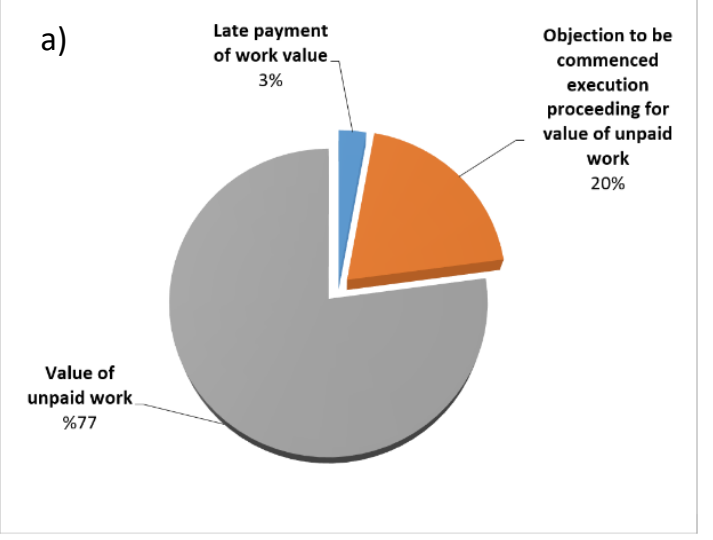

b)

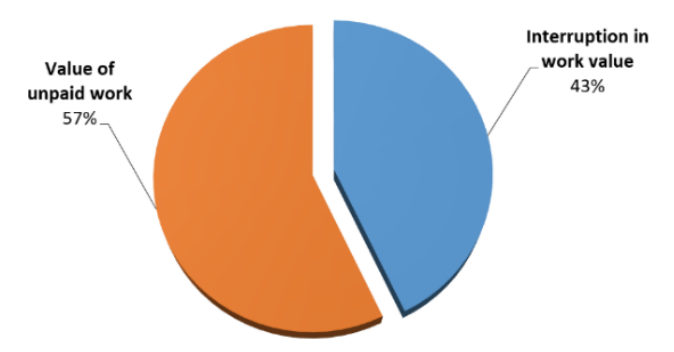


Figure 8. The results of winning party for unpaid work value-induced dispute according to decisions of court of cassation and HTB. (Self-Elaboration).

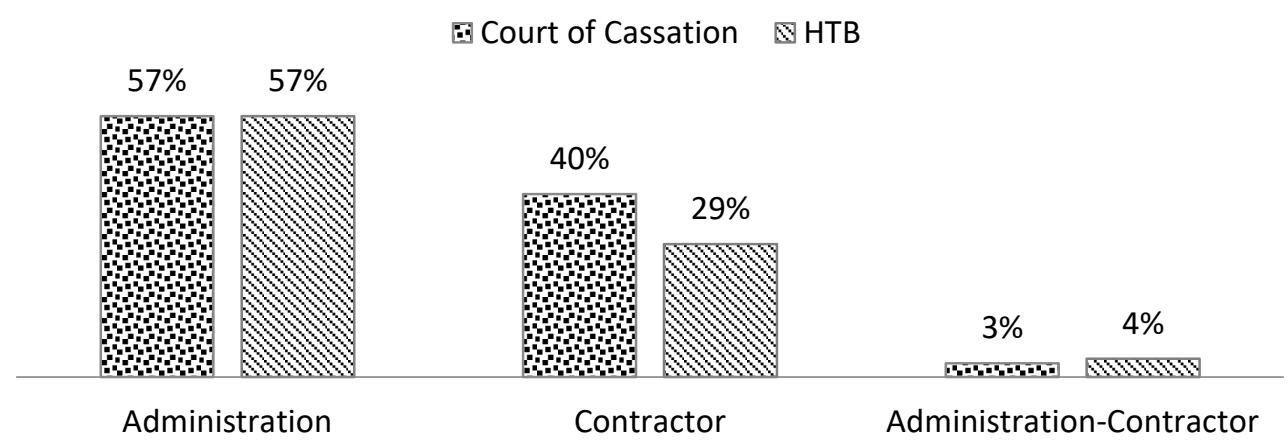

35 of 174 cases in court of cassation and 7 of 84 HTB decisions are about value of unpaid work. The situations leading to dispute class and proposals to resolve the dispute are listed in five points:

- Since risk distribution is not balanced between parties, contractor undertakes significant rate of the risk and does not receive support from administration in taking effective steps to ensure the continuity of implementation. For example, although contractor requests for the price that is deserved, administration responds negatively to the request based on the protective provisions included in the contract. Due to this reason, it causes dispute between parties. Even if a contractor makes a move to compensate for the errors in project, this situation is not considered by administration. Balanced distribution of risk is explained in detail in FIDIC Red and Yellow Book in order to prevent the dispute provided. As a similar step, necessary arrangements should be implemented in GCCW for balanced risk distribution.

- In consequence of administration does not pay without reason, contractor demands the work value deserved and this situation causes a dispute between parties. Administration is only authorized to apply to HTB delegation. As a result, limited number of appeals regarding this dispute is an indication of the arbitrary action of administration. In order to fulfill contractor's claims, responsibilities of administration towards contractor should be checked by introducing objective engineer and DAAB. In addition, penal sanctioning should be arranged to prevent arbitrary treatment of administration.

- Contractor suffers financial and moral damage as a result of late payment of contractor's deserved work value by administration. This situation causes dispute between parties. To prevent the dispute, necessary provisions should be added to the contracts for the payment of the work value deserved by contractor on certain dates. In FIDIC, if administration makes the progress payments late, contractor deserves to receive the monthly compound financing cost based on the unpaid amount. In case of delays in progress payments at FIDIC, contractor deserves to receive the monthly compound financing cost based on the value of unpaid work. Furthermore, additional costs due to late payment are also paid by administration. Considering the issues, revisions should be made in GCCW to check whether work value is paid or paid on time by administration. Then, penal sanction should be applied, which takes into account the delay period. Addedly, arrangements in GCCW should be made to compensate economic damage and profit loss contractor due to late payment.

- Administrations do not have right to do work without bids in accordance with the provisions of Public Procurement Authority and Public Procurement Contracts Law. On the other hand, classifying decisions of Court of Cassation, it is determined that construction works are carried out without operating bid process. Construction works to be done within the scope of the bid are performed based on provisions of acting without authority in Turkish Code of Obligations. In this case, a dispute developed as a result of not paying the work value to contractor. To prevent this negative situation, implementation of provisions of Public Procurement Authority and Public Procurement Contracts Law should be regulated in construction works. To this end, arrangements should be exerted in the provisions.

- Some tests are requested from contractor at the application stage by technical team of administration. Expenses of contractor for tests are not covered by administration and this situation causes dispute. In case of the tests result in verifying application, arrangements in GCCW should be paid costs by administration, as in FIDIC standard forms.

\section{Defective, incomplete or faulty in work-induced dispute}

Contractor has responsibilities to administration during implementation of public construction projects. At the beginning of these, stipulated works are completed in compliance with engineering rules and technical conditions in accordance with administration's demands. For this reason, the work must have the qualifications specified in the contract and technical specifications. Otherwise, defective, incomplete or faulties regarding work cause dispute between parties. Defective, incomplete and faulty-induced disputes constitute $20 \%$ of disputes determined based on 
Court of Cassation's judgments. Analyzing decisions of the Court, works are categorized as under the titles; i. defective, incomplete and faulty, ii. hidden-defective, and iii. the others (Figure 9). It is presented that the distribution of the winning party determined in relation to the dispute based on the Court decisions in Figure 10. In 35 of Court decisions regarding the dispute, $94 \%$ of the decisions of local court are vacated, $3 \%$ approved and $3 \%$ approved remedially.

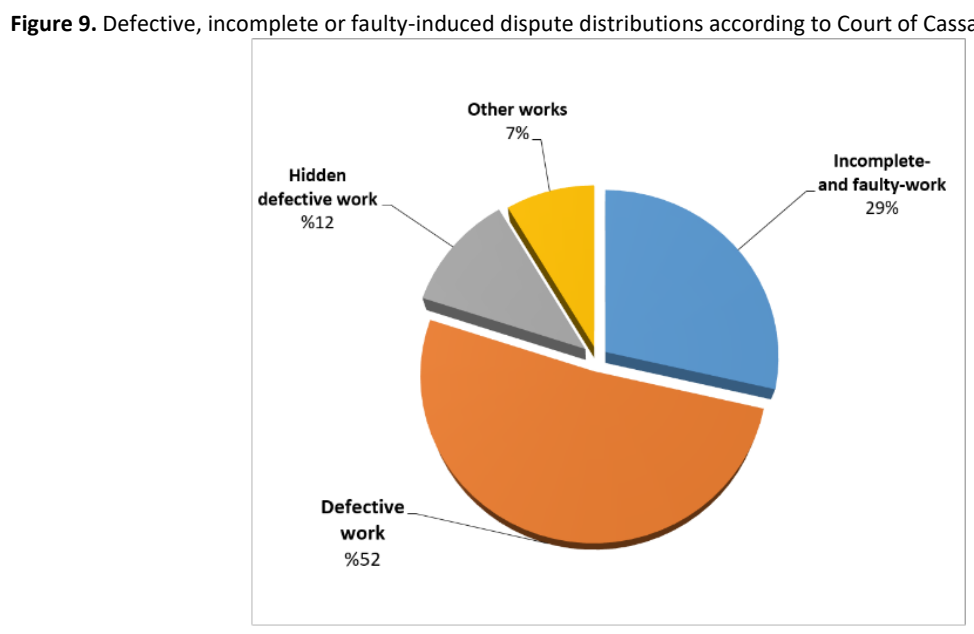

Figure 10. Results of winning party for defective, incomplete or faulty-induced dispute according to judgments of Court of Cassation. (Self-Elaboration).

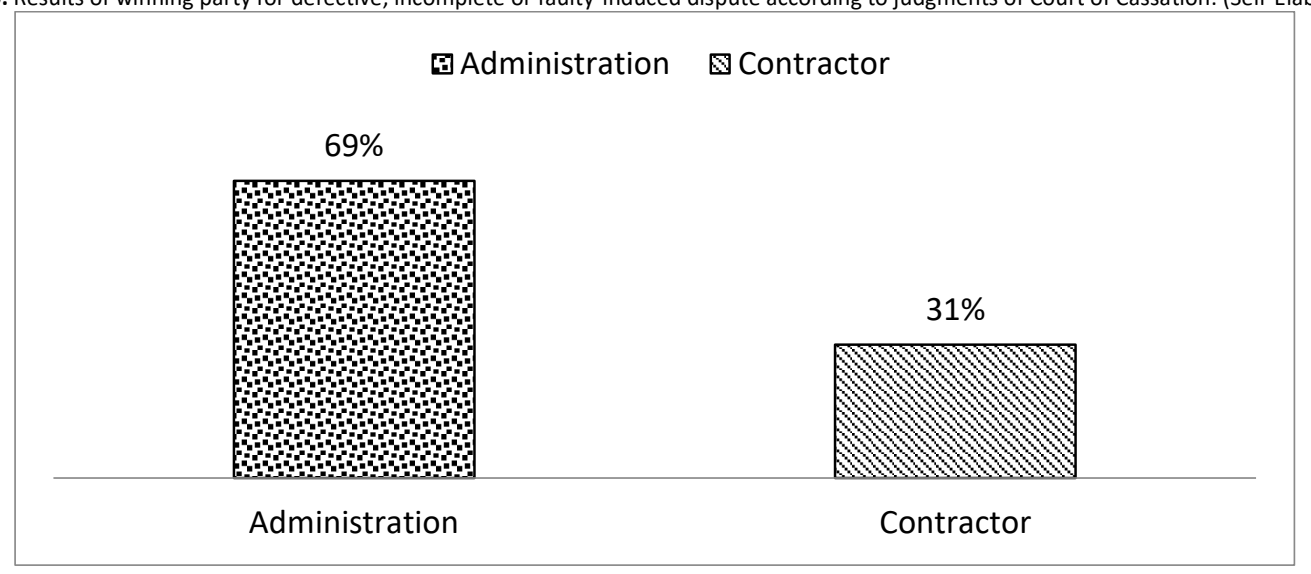

35 of 174 the Court judgments are about works with related to defective, incomplete or faulty. The situations causing the dispute class and the suggestions for the prevention of the dispute are specified under four main headings:

- Emergence of defective-, incomplete-, and faulty-works in public construction projects is a result of the improper and insufficient inspection mechanism. In this case, administration requests contractor to fulfill its responsibilities, and contractor appeals in return. To prevent this, the inspection effective needs to be improved. To this end, the current value of building inspection companies should be escalated as well as the number of engineers - building control officer- to be employed per project should be increased. Indispensable arrangements should be implemented in Construction Inspection Law for this purpose.

- It causes dispute between parties regarding the construction quality due to significant design errors in projects prepared by administration. In order to prevent this, project control should be carried out by the expert technical team assigned by administration. Additionally, administration should receive support from contractor in design, as in FIDIC. This support will lead to a decrease in budget and shortening in project duration. Arrangements for these issues, which are stated depending on all these reasons, should be made in GCCW.

- In case the faults in project and its annexes are not noticed by contractor or if no objection is made to administration within fifteen days, contractor is held responsible for financial loss. Thus, the risk distribution between administration and contractor is not balanced, and this leads to a dispute between parties. According to FIDIC, if an error is determined in projects and annexes prepared by administration and referenced by contractor, the loss reserve is paid to contractor by administration, in addition, contractor is given a time extension for the work. However, if there is no objection by contractor in GCCW, no loss reserve or time extension is given. In order to prevent all these negative situations, the provisions in GCCW should be arranged in accordance with FIDIC.

- When the new contractor undertakes the work due to the transfer or annulment of the contract during implementation of project, the completed work items -current situation-cannot be determined correctly in 
most cases. Therefore, dispute is emerging between parties in determining the liable party for the defective, incomplete or faulty works. DAAB, as described in FIDIC Red Book, should be occurred to determine the existing construction level before the site delivery to the new contractor. In this way, the dispute can be prevented.

\section{Subtitle Project duration, time extension and work schedule-induced dispute}

In implementation phase of public construction projects, work schedule is lead to disruptions due to manufacturing changes, mandatory reasons and the failure of both parties to fulfill their responsibilities on time. Therefore, the disruptions and changes in project duration result in cost and quality problems. Project duration, time extension and work schedule-induced dispute constitute $21 \%$ and $8 \%$ of the disputes determined based on Court of Cassation- and HTB-decisions, respectively. This dispute class in the Court decisions can be summarized as follows: i. late payment of the debt not in line with work schedule, ii. nonpayment of a debt within a specified period, iii. nonpayment of a debt within a specified time extension, and iv. other topics. Comparably, HTB decisions in related to the same dispute class is determined as: i. nonpayment of a debt within a specified period, ii. time extension in work, iii. reduction in work duration (Figure 11). The results of the Court- and HTB-decisions for the winning party are given in Figure 12. Regarding this dispute, the Court reversed $97 \%$ and remedially approved $3 \%$ of judgments of local court.

Figure 11. Project duration, time extension and work schedule-induced dispute distribution according to (a) The court judgments, (b) HTB decisions. (Self-Elaboration).

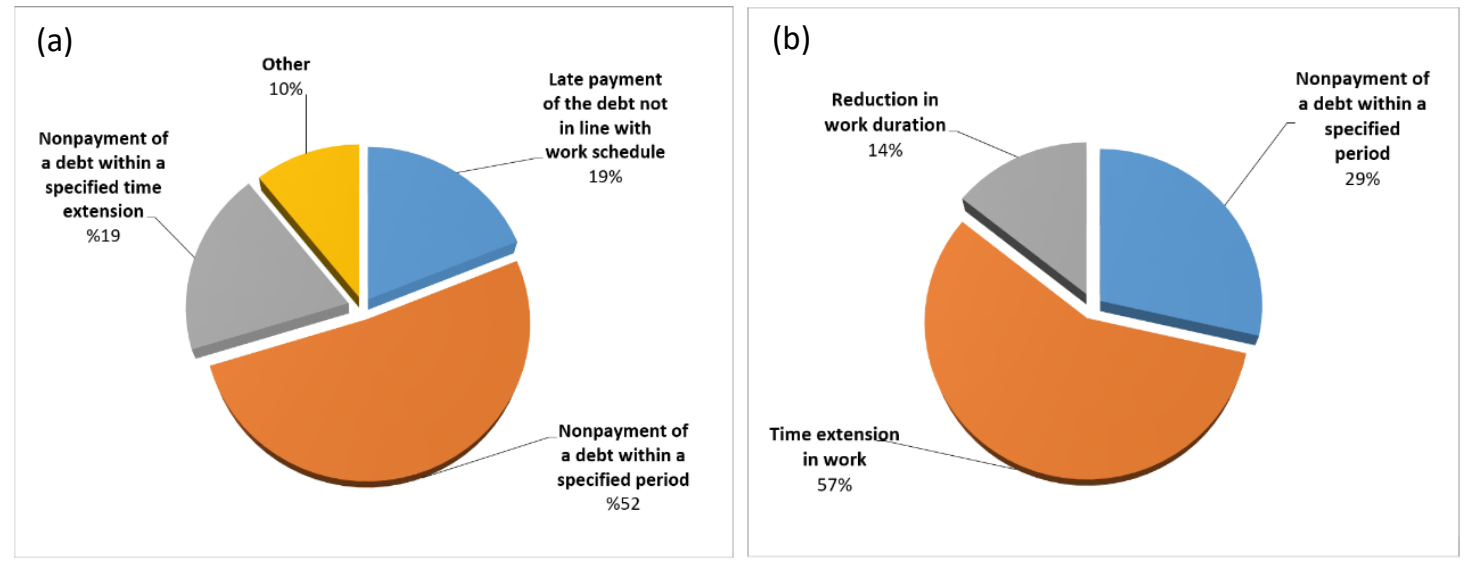

Figure 12. Results of winning party for project duration, time extension and work schedule-induced dispute. (Self-Elaboration).

Court of Cassation $\mathrm{N}$ HTB

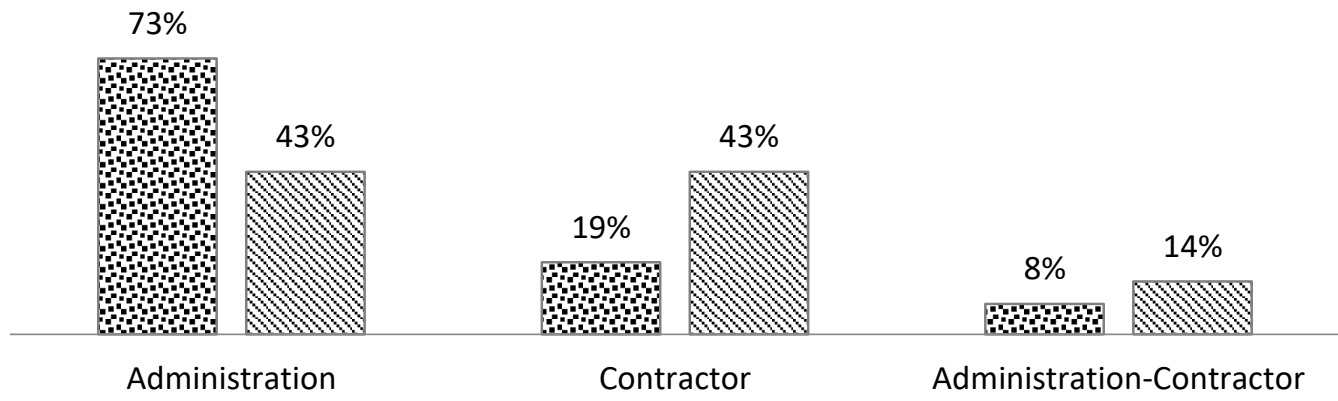

37 of 174 the Court judgments and 7 of 84 HTB decisions are about project duration, time extension and work schedule. In this dispute class, the situations causing the dispute and suggestions to prevent these disputes are listed in below:

- The indirect and other expenses, incurred by contractor due to the late site delivery, are not covered by administration. It causes dispute between parties. Administration only gives time extension to contractor in order to compensate for the late site delivery. Therefore, the expenses of contractor regarding this delay are not paid by administrator. In FIDIC Red Book, contractor expenses are compensated by administration, if requested. That being the case, arrangements similar to FIDIC approach should be made in GCCW, and contractor's expenses should be supported on this subject.

- Despite the delay in the process to get a building license, no time extension is not in question. This lead to dispute between administration and contractor. In order to prevent the dispute, the period of building license should be foreseen in advance and specified in the contract by administration. Additionally, the time extension must be given when the specified period is exceeded, and contractor's expenses in this process must be determined and subsequently paid. 
- Contractor suffers financial- and time-losses due to the fact that the application instructions of administration technical staff are not given to contractor in a timely manner. According to GCCW, contractor's pecuniary loss is not compensated by administration and thus this lead to dispute between parties. In order to avoid the dispute, the provisions that cover the time and financial loss must be arranged in GCCW in accordance with FIDIC Red Book.

- Administration can act arbitrarily because there is no regulation in GCCW regarding the construction site. For example, in spite of late site delivery, contractor's demands are responded negatively by administration and in conclusion, a dispute can occur. While there is no regulation for the maximum duration of site delivery in GCCW, that in FIDIC is 42 days. In FIDIC, if this period is exceeded, administration make amends the demands regarding financial- and time-losses of contractor. For this reason, disputes can be prevented by preparing provisions in this direction in GCCW.

\section{Contract's annulment and administrative policies-induced dispute}

Contract may be annulled by administration due to the failure of contractor to perform on time and at the desired level except for force majeure at any stage of implementation phase of public construction projects. In the process, parties fall into dispute in terms of the reason and results for the annulment. $17 \%$ and $6 \%$ of the disputes determined depending on the decisions of Court of Cassation and HTB arise from contract's annulment and administrative policies, respectively. The dispute class handled at the Court follows as; i. annulment of the contract, ii. overpayment-induced administration loss, and iii. administrative policies, while the class in HTB is determined as; i. notification of technical staff to administration and its realization, and ii. other titles (Figure 13). Results of the court- and HTB-decisions in terms of winning parties is given in Figure 14. The court reversed majority (\%97) of the decisions of local court and thus only approved on ratio 3 percent.

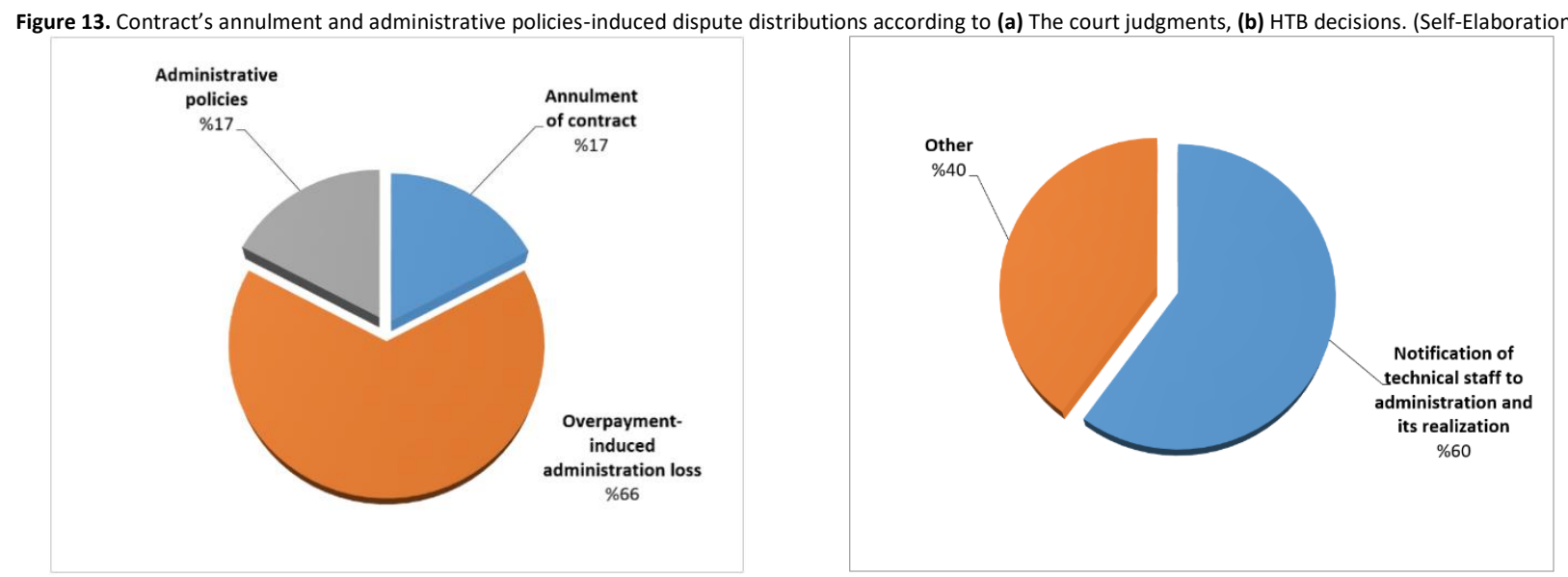

Figure 14. Results of winning party for contract's annulment and administrative policies-induced dispute. (Self-Elaboration).

Court of Cassation $\mathrm{QHTB}$

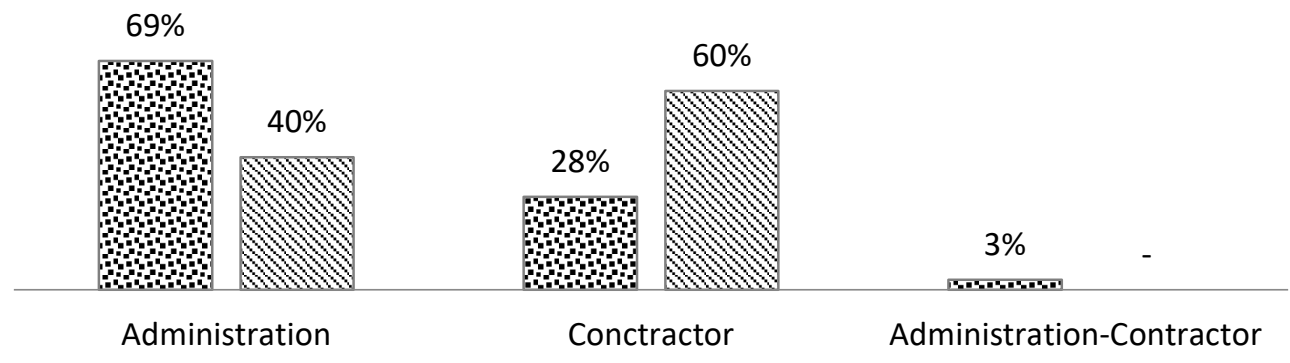

29 of 174 court judgments and five out of 84 HTB decisions are about the annulment of contracts and administrative policies. The sample cases causing the dispute and suggestions to prevent the disputes are listed below.

- In the event of force majeure, 20-day period given to contractor in GCCW is not sufficient. When the period is exceeded, parties fall into dispute due to the claims of both parties during the annulment of the contract. In GCCW, parties should be given the right to terminate the contract in case of they have to break work for uninterrupted 84 days or 140 days in total due to force majeure as in FIDIC. 
- As a result of supervision of chamber of accounts after final progress payment, it is determined that administration is subjected to financial damage due to fictitious manufacturing and inflated quantities. As soon as this situation is determined, it causes dispute between parties. This shows that supervision and professional experience of technical staff are insufficient. In the case of public's financial loss occurs, the preparation and surveying of projects, inspection of progress payments and preparing final progress payment should be executed by expert and experienced engineers. At the bid stage, technical specification must be prepared accurately and completely. In addition, the consultancy service should be tasked by administration during implementation of the contract. According to the professional experience of the technical staff, construction inspection liability should be provided over contract value.

- Contractor must assign to workers and technical staff requested by administration. If contractor does not fulfill this obligation, administration imposes penal sanctions. Depending on this situation, the amount and scope of the penalty leads between parties. To prevent the dispute, general provisions for contractor's representative and employment should be added to GCCW. In addition, necessary arrangements should be included in the contract specific by detailing the technical staff, number of workers and working days.

- In cases that the bid is canceled by administrative court, and public construction project is removed from the investment program with the decision of the Council of Ministers, contractor is financially damaged due to the annulment of the contract. Thus, parties fall into dispute regarding the compensation of the loss. In this case, arrangements should be compensated financial loss and the depreciation of collaterals for contracts in administrative transactions depending on annulment of the contract caused by contractor's defect.

\section{Unit price-induced dispute}

Due to the mandatory changes in implementation phase of public construction projects, administration and contractor come together to settle the unit prices of the non-project work items. However, it causes dispute between parties in the determination of unit price of new work items needed due to the increase in work as well as existing unit prices accepted by parties in the contract and its annexes. HTB is authorized for the resolution of disputes in determining the prices of work items that are not accepted by contractor despite being determined by administration. Unit prices to be determined by the board are obliged to be accepted by both administration and contractor. The dispute class in HTB decisions is categorized as; i. content of bid unit price, and ii. fixing of new unit price (Figure 15). The distribution of winning party of 17 HTB decisions on the dispute is given in Figure 16.

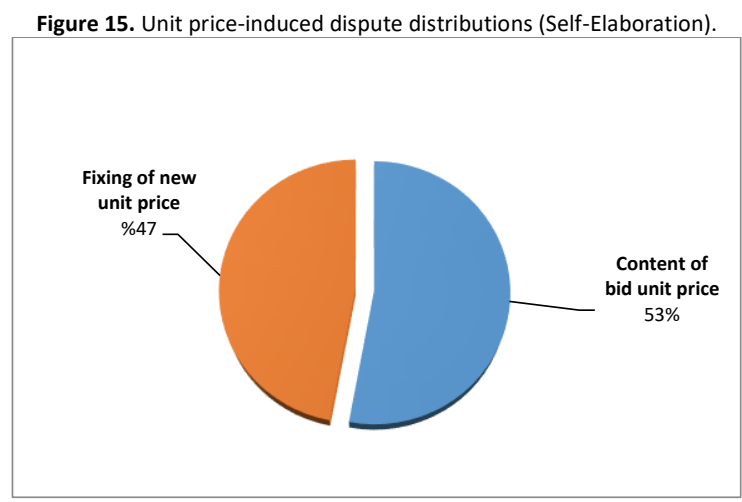

Figure 16. Results of winning party in unit price-induced dispute. (Self-Elaboration).

ऽ HTB

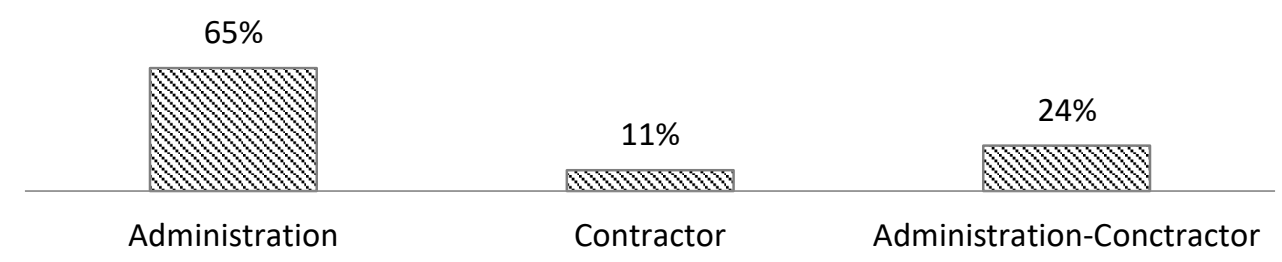

Analyzing HTB decisions, 17 of 84 HTB decisions are about unit price. The situations causing the dispute regarding unit price and suggestions preventing dispute are listed below.

- Inadequate-, incompatible- and undetailed-building projects lead to mandatory project changes during implementation phase. Project changes cause the need for new work items and parties fall into dispute during 
the determination of related unit prices. It is understood that the increase or decrease in work-induced disputes lead to the unit price-induced dispute. For this reason, it should be detailed that professional experience and work completion regarding the adequacy of the technical team assigned by contractor. In addition, the adequacy of subcontractors should be revised. In addition, contractor must review the technical specifications in sufficient time without missing any details. Examination period of the technical specifications by contractor is 15 days in GCCW. The period must be 52 days as specified in FIDIC Red book. Thus, insufficient duration-induced disputes will be prevented

- In addition to the fact that the technical specification is not clear, due to analysis and description of unit price are not suitable, contractor has not comprehensive knowledge the details, scope and cost of the work. Therefore, it activates dispute between parties regarding scope and amount of the unit price during the application of work. Additionally, it causes a dispute in case of the unit price determined by HTB is incorrect. Based on this point, the experienced and knowledgeable staff should be assigned during the preparation of the technical specifications. A wide field research should be done by increasing the number of technical staff should be performed in order to prepare unit price analysis without errors. Likewise, unit price analysis methods need to be developed by HTB. Guidelines that provide an understanding of the specifications should be prepared for technical specifications with contract annexes.

- Since contractor does not examine the annexes of the contract, especially unit prices of the work items in detail, contradictory and incompatible unit prices are determined during implementation phase and parties fall into dispute. In FIDIC Red Book, modifications can be made on the unit price in changes that cause an increase in the work of contractor. Starting from this point, the unit price should be updated as a result of the changes made within project as a result of the change in technical issues in GCCW.

- In restoration works, in case of the examinations performed by the advisory committee in the application stage, the changes in project can be requested by the committee. The process of determining unit prices regarding the new business items needed depending on the changes leads to dispute between parties. In order to prevent this situation, arrangements should be made to carry out the evaluations by the committee at the preliminary project stage prior to implementation in GCCW.

There is no solution other than official judgment for disputes that occurred during implementation phase of public construction projects. If parties apply to official judicial remedy for resolution of dispute, local court decisions are reversed by Court of Cassation. In this context, examining decisions of the Court, $97 \%$ of local court decisions are reversed by Court of Cassation and returned to local court, and $3 \%$ of those are approved remedially. This situation causes both parties to be exposed to pecuniary loss and intangible damages. In addition, public service is disrupted due to not performed in desired, quality and time appointed of public construction projects.

In the study presented, disputes that occurred during implementation of contracts for public investment projects are examined in terms of Court of Cassation and High Technics Board (HTB) decisions. In this context, 174 decisions between 2015 and 2018 in the Court and 84 decisions between 2005 and 2015 in HTB are examined considering disputes in public construction projects. On the basis of judgments of the Court, it is determined that the most dispute occurred in increase or decrease of work-induced disputes with 22 percent in projects. The dispute class is followed by the other dispute classes regarding project duration, time extension and work schedule (21\%), defective, incomplete and faulty work $(20 \%)$, value of unpaid work (20\%) and annulment of contract, administrative policies (6\%). Likewise, in public construction projects based on HTB decisions, the most dispute is again on increase or decrease-induced dispute with $57 \%$. This dispute class is attended by disputes about unit price $(21 \%)$, project duration, time extension and work schedule (8\%), value of unpaid work (8\%), and contract's annulment and administrative policies $(6 \%)$.

Based on the disputes classified under six subtitles in Section 3, the proposal for the resolution procedure of dispute is shown in Figure 17. The construction process in Turkish public construction projects is carried out according to the GCCW provisions (Figure 3). Looking at the Court of Cassation and HTB judgments of the current GCCW provisions, it is seen that there is a conflict-producing unity of provisions. It is thought that these deficiencies will be eliminated with the beneficial processes and provisions of the FIDIC standard contract, which has international validity and continuity. Thus, a procedure that will provide a solution between the parties by providing a more fair and balanced risk distribution of the conflict without resorting to official resolution paths has been put forward. Thanks to this procedure, the risk distribution between the parties against the contractor has been revised to be equal. The "engineer" status has been established at an equal distance between the parties. In this way, an authority has been created that will protect the interests of the parties equally at every stage of the project. In cases where the engineer's decision is not accepted by the parties, a DAAB delegation to be determined jointly by the parties has been established. In this way, the decision of 
the expert committee in the field was more acceptable and reaching a solution was more feasible. It has been proposed and recommended for the parties to use Alternative Dispute Resolution methods other than official solutions. In addition, the arbitration process has been formalized and made a part of the practice. All the mentioned processes are linked to the calendar, making the legal proceedings of the parties easier. This procedure is envisaged to be an effective tool for the solution of the disputes.

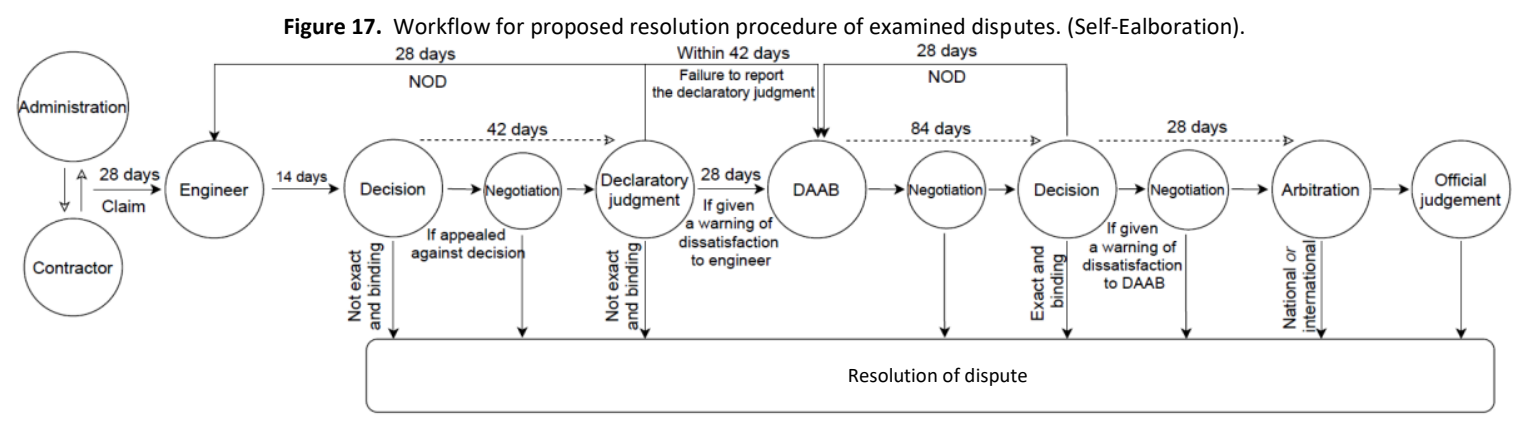

Evaluating the data obtained within the scope of the study, proposals for arrangement of GCCW are listed below:

- The emergence of defective, incomplete, faulty and hidden defective works during and after implementation of public construction projects is an indication that building inspection system is not effective. The reason for this may be the insufficient number and/or the lack of experience of technical staff. In order to eliminate this situation, building inspectors in sufficient number and experience should be employed.

- Examining the content of GCCW in detail, it is seen that there is an approach for the protection of public interest. Considering the risk distributions of administration and contractor based on the contract, it is understood that there is the distribution in favor of administration. Therefore, it is needed to radical changes to balance this risk distribution.

- According to Court of Cassation- and HTB-decisions, it is seen that the most dispute is about the increase or decrease in work. Parties should be ensured to reach a resolution through negotiation instead of costly and long-term official judgment. For this reason, it is necessary to define DAAB as well as an expert, experienced and impartial engineer to convey their claims of parties for GCCW. Thus, as in FIDIC Red Book, an engineer and DAAB should be assigned to resolve the disputes by negotiation. Considering that the delegation consists of experts who are experienced in engineering, the dispute will be resolved in a short time.

- There are no regulations regarding the demands of contractor in GCCW. In this context, engineers and delegations should be assigned by defining their claims. When the contract is signed for projects with a value of 1,000,000.00 USD, the aforementioned engineer and DAAB should be included in project. This assignment should be made when a dispute arises in projects with a price below 1,000,000.00 USD. In this respect, the evaluations of DAAB consisting of expert and experienced engineers and lawyers can be made in a shorter time, more effectively and less costly than official judgment.

- Although there are provisions in GCCW regarding supervision of contractor's responsibilities towards administration, there is no condition regarding the control of the responsibilities of administration (payment, delivery, construction license purchase, etc.) against contractor. For this reason, now and then, contractor is subjected to financially loss due to late payment and sometimes due to the lack of a building license. In such cases, arrangements should be made for impose penal sanctioning to administration.

- Due to deficiencies and errors in projects prepared by administration, contractor is only given a time extension. This is the result of the insufficient 15-day period specified as the examination period for contractor in the contract and specification in GCCW. In case of expiration of this period, contractor does not make a request from administration. In order to prevent this unfair situation, this period should be increased to 52 days as in FIDIC. Thus, technical specifications can be examined by contractor in no uncertain terms.

- Arrangements should be made in GCCW to pay for expenses incurred by contractor due to an administrativeinduced error. As a result of the examination and audit made by exchequer court, administration is subjected to financial loss due to overpayment. In order to prevent the public inspection from being insufficient and vulnerable, technical specification should be prepared accurately and completely at the bid stage. In addition, consultancy engineering service on behalf of administration should be enabled during implementation of the contract.

The issues to be drawn from the results of this study can be given below as two items:

- Project management covers civil engineering, business- and law-disciplines. In order to have equipment to prevent and eliminate dispute occurred in project management, a good level of legal knowledge is required in addition to business and technical knowledge. Depending on the justification, construction law courses should 
be adequately included in the curriculum of institutions providing technician and engineering education.

- Local courts make erroneous decisions due to incomplete review and incorrect evaluation. However, judges, insufficient professional experienced, are the decision-makers in disputes in public construction projects. For this reason, judges with professional experience should be appointed especially in the solution of high-budget public construction projects. Judges also are misled due to unrealistic reports prepared by commission of experts. For this reason, criteria for selection of experts to be employed in expertise should be revised in terms of professional experience and competence.

\section{Acknowledgments}

The paper is prepared by using the data of master thesis titled "Investigation in the framework of jurisdictions of disputes in public construction". The authors would like to specifically thank Assistant Professor Cemil Akcay, Department of Architecture, Istanbul University, for his valuable discussions at all stages of the thesis process.

\section{References}

Apanoğlu, E. C. (2007). The analysis of disputes in the construction sector that emerge from the periods and source of uncared debts which are passed onto jurisdiction, MSc. Thesis, Science Institute, Çukurova University (in Turkish).

Aydemir, E. (2016) Work contract and construction law, Seçkin Publishing, Ankara, Turkey (in Turkish).

Aydın, Y. (2010). Dispute resolutions on the FIDIC based investment projects, MSc. thesis, Institute of Social Sciences, Istanbul University (in Turkish). Balcı, M. (1999). Resolution paths for conflicts, and Arbitration, Danışman publishing, Istanbul, Turkey.

Bilaloğlu, B. (1995). The Conflicts reasons in construction contlacts and analysing of the proposed solutions, MSc. Thesis, Science Institute, Istanbul University (in Turkish).

Bozkurt, M. (2002). Arbitration in construction disputes resolution, MSc. thesis, Science Institute, Istanbul Technical University (in Turkish).

Chan, D. W., \& Kumaraswamy, M. M. (1997). A comparative study of causes of time overruns in Hong Kong construction projects, International Journal of Project Management, 7(1), 55-63.

Çakmak, F. P. (2014). Reconstruction of standard contract documents used in the Turkish public construction procurements, PhD thesis, Science Institute, Istanbul Technical University (in Turkish) .

Çevikbaş, M. (2018). An investigation of judicial dispute resolution in Turkish construction industry, MSc. thesis, Science Institute, Yıldız Technical University (in Turkish).

Eken, B. (2005). Disputes in construction contracts, resolution techniques and an upon the disputes resolved by ligitation in Turkey, MSc. thesis, Science Institute, Istanbul Technical University (in Turkish).

Ereli, Y. (2014). Comparative analysis of FIDIC-Red Book and the Turkish public procurement legislation, MSc. Thesis, Science Institute, Bülent Ecevit University (in Turkish).

Fenn, P., \& Gameson R. (1992). Construction Conflict Management and Resolution, E \& F N Spon London.

FIDIC (2015). Statues and by-laws, International Federation of Consulting Engineers, fidic.org/sites/default/files/ FIDIC\%20Statutes_2015_0.pdf [Accessed on January 12, 2019]

FIDIC (2017) Conditions of contract for construction, 2nd edition, FIDIC, Geneva, ISBN: 978-2-88432-084-9.

FIDIC (2019a). About Publications, fidic.org/bookshop/about-publications [Accessed on January 11, 2019].

FIDIC (2019b). Which FIDIC contract should I use?, fidic.org/node/149 [Accessed on January 11, 2019].

Garsonnet, E. (1912). Traite theorique et pratique de procedure civile et commerciale: en justice de paix et devant les conseils de prud'hommes, Recueil Sirey, pp. 384.

Genç, H. (2014). Disputes and dispute resolution recommendations for lump sum turnkey contracts under The Public Procurement Law in Turkey, MSc. thesis, Science Institute, Istanbul Kültür University (in Turkish).

Goodman, A. (2017). Preparing for mediation. Guide for the benefits from mediation, Translation: A. Bıçaksız and Z. Alkın, Republic of Turkey Ministry of Justice, Department of Publishing Affairs, Ankara, Turkey (in Turkish).

Hancock, M. (1992). Educating Construction Professionals to Improve the Built Environment, Construction Conflict Management and Resolution, 2527 September 1992, London, E \& FN SPON, 400-405.

Hellard, R. B. (1992). Construction Conflict-Management and Resolution, Construction Conflict Management and Resolution, 25-27 September 1992, London, E \& FN SPON, 34-45.

HTB (2015). Decisions and Opinions, Republic of Turkey Ministry of Environment and Urbanization, Directorate of High Technics Board, Ankara, Turkey (in Turkish). 
ICC (2012). Arbitration rules of International Chamber of Commerce, icc.tobb.org.tr/docs/ICC_Tahkim_Kurallari_Kitapcik.pdf [Accessed on February 2, 2019] (in Turkish).

INTES (2018). Report on construction sector, The Turkish Employers' Association of Construction Industries, intes.org.tr/wpcontent/uploads/2018/11/SEKT\%C3\%96R-RAPORU.pdf [Accessed on January 15, 2019] (in Turkish).

ISTAC (2017). Arbitration rules of İstanbul Arbitration Center, istac.org.tr/wp-content/uploads/2016/03/istac_tahkim_kurallari_v3_TR.pdf [Accessed on February 3, 2019].

ISTAC (2018). ISTAC in Numbers, istac.org.tr/wp-content/uploads/2018/05/rakamlarla_istac_tr.pdf [Accessed on February 3, 2019] (in Turkish).

ITOTAM (2017). Arbitration rules of İstanbul Chamber of Commerce, Arbitration and Meditation Center itotam.com/Dosyalar/2018/ITOTAM\%20Tahkim\%20Kurallari-\%202017.pdf [Accessed on February 4, 2019] (in Turkish).

Kerzner, H. (2009) Project Management: A Systems Approach to Planning, Scheduling and Controlling, John Wiley \& Sons Inc, New York.

KiK (2017). Annual report for Public Procurement Authority, dosyalar.kik.gov.tr/genel/IhaleGovTr/KIK_2017_Faaliyet_Raporu_web.pdf [Accessed on February 10, 2019] (in Turkish).

Koldaş, B. (2008). FIDIC dispute procedures, MSc. thesis, Institute of Social Sciences, Gazi University (in Turkish).

Koral, R. (1947). Arbitration in Our New and Old Law, Journal of Faculty of Law, Istanbul University, $193-218$ (in Turkish).

KPMG (2018). Sectoral overview, assets.kpmg/content/dam/kpmg/tr/pdf/2018/02/sektorel-bakis-2018.pdf [Accessed on December 14, 2018] (in Turkish).

Langford, D., Kennedy, P., \& Sommerville J. (1992). Contingency management of conflict: Analysis of contract interfaces, Construction Conflict Management and Resolution, 25-27 September 1992, London, E \& FN SPON, 63-70.

Mersinkaya, S. (2010). Disputes of parties in construction contracts in scope of building construction and proposals for solution, MSc. thesis, Science Institute, Yıldız Technical University (in Turkish).

Murdoch, J. R., \& Hughes W. (1992). Building contract law. Longman Law, Tax and Finance.

OCTC (2019). Overseas Contracting Technical Consultancy, Republic of Turkey Ministry of Trade, ticaret.gov.tr/hizmet-ticareti/yurtdisi-muteahhitlikteknik-musavirlik [Accessed on February 22, 2019] (in Turkish).

Öz, B. (2012). A fuzzy logic resolution model for conflicts encountered in public construction projects, PhD thesis, Science Institute, Istanbul University (in Turkish).

PMI (2013) Project management Knowledge guide, Fifth version, Project Management Institute Turkey (in Turkish)

Smith, M. C. (1992). Facing up to Conflict in Construction, Construction Conflict Management and Resolution, 25-27 September 1992, London, E \& FN SPON, 26-33.

TBA (2002). Arbitration directive of Union of Turkish Bar Associations, barobirlik.org.tr/dosyalar/duyurular/tahkim_yonetmeligi.pdf [Accessed on February 21, 2019] (in Turkish).

TMB (2019). Is World reshaping while entering 2019 ? tmb.org.tr/arastirma_yayinlar/tmb_bulten_ocak2019.pdf [Accessed on January 18, 2019] (in Turkish).

Uyanık, N. (2004). Contract management in construction works (Theoretical and Practical Information), Beta publishing, Istanbul.

Watts, V. M., \& Scrivener J. C. (1992). Review of Australian Building Disputes Settled by Litigation, Construction Conflict Management and Resolution, 25-27 September 1992, London, E \& FN SPON, 210-220.

Zikman, R. V. (1992). Successful conflict management, Construction conflict management and resolution, 25-27 September 1992 , London, E \& FN SPON, 53-57. 